\title{
Sistem Arsitektur Berwawasan Lingkungan
}

\author{
Rochadi Mahalalita dan Johanes Krisdianto \\ Departemen Arsitektur, Fakultas Teknik Sipil dan Perencanaan, Institut Teknologi Sepuluh Nopember (ITS) \\ e-mail: john_kris@arch.its.ac.id
}

\begin{abstract}
Abstrak - Dewasa ini semakin meningkatnya angka kejahatan seksual terhadap anak mengakibatkan timbulnya rasa tertekan tidak percaya diri. Beberapa dampaknya seperti penyalahgunaan konsepsi lingkungan yang besar, jangka panjang, fisik maupun mental pada anak-anak. Studi ilmiah dan observasi lapangan di Surabaya, Jawa Timur menunjukkan tingginya tingkat kekerasan seksual terhadap anak-anak di berbagai lapisan dari anak-anak dan orang dewasa. Meskipun studi yang sangat heterogen, terdapat berkorelasi pelecehan pada tingkat yang berbeda. Trauma adalah peristiwa dramatis dalam kehidupan yang mengancam kehidupan kesehatan atau bahkan ego individu yang bersangkutan. Efek terburuk trauma membuat korbannya menderita Post Traumatic Stress Disorder PTSD yang merupakan kondisi stres pasca trauma akibat pengalaman yang mengerikan baik fisik fisiologis atau kombinasi keduanya. Arsitektur berwawasan lingkungan dengan pendekatan arsitektur perilaku, diharapkan menjadikan sosok arsitektur yang unik dan didukung penggunaan elemen arsitektur yang sesaui dengan uraian isu yang diangkat.
\end{abstract}

Kata Kunci-Arsitektur lingkungan, Arsitektur perilaku.

\section{PENDAHULUAN}

I SU tentang kajahatan seksual sering terdengar di akhir tahun 2015 hingga awal 2016. Di mana isu dan berita tersebut hanyalah sekedar berita. Dan informasi tentang pemetaan lingkup kasus yang terjadi. Sebagai tambahan mungkin hanya kronologi kejahatan tersebut terjadi. Sisanya hanya menarik simpati sebagain manusia lain untuk berpartisipasi dan berempati terhadap peristiwa tersebut. Sebagaian objek peristiwa tentang kejahatan seksual berporos kepada bagaimana kasusnya, lalu dampaknya apa saja. Dampak dalam hal ini hanya sebagai objek. Bukan sebagai subjek. Dalam hal ini muncul beberapa pertanyaan. Bagamana merespon dampak tersebut dalam sudut pandang subjek yang terlibat. Serta dihubungkan dengan konteks arsitektur sebagai framework yang akan dijalankan.

Tanggung jawab arsitek terletak pada rancangan bangunan, yaitu ruang tertutup untuk kegiatan manusia. Tetapi, bangunan tidak berada dalam keterpencilan. Mereka berada dalam konteks ruang, perilaku dan persepsi. Pengkajian perencanaan tapak sering tersusun dalam dua komponen yang berhubungan yaitu (Snyder dan Catanese, 1984:181).

Sehingga dirasa perlu adanya sistem adukasi dalam sebuah 'ruang' gerak bagi anak-anak. Untuk sekedar menjalin hubungan social dengan lingkungannya. Selain itu juga sebagai implementasi terhadap respon sistim energi alternatif dalam menunjang inovasi dalam konteks arsitektur. Sistem ini lebih kepada perencanaan teknis dalam utilitas bangunan tersebut. Meliputi sistem kelistrikan, sistem air bersih, sistem pencahayaan dan penghawaan, fire protection, serta sisanya adalah konsep ruang luar yang mengutamakan wawasan lingkungan sebagai sarana edukasi bagi anak-anak.
Hal tersebut tidak terlepas berangkat dari isu dan konsep pendekatan arsitektur yang diangkat. Pendekatan arsitektur vernakular dalam konsep perancangannya, sehingga menuntut adanya hubungan keterkaitan antar aspek satu sama lain. Arsitektur vernakular secara umum sendiri merupakan implementasi dan modifikasi dari konsep arsitektur Nusantara. Di mana aspek utamanya ialah orientasi dari sistem bangunan tersebut, serta aspek aktivitas yang dinaungi di dalamnya. Aspek orientasi sistem tersebut diimplementasikan ke dalam sistem teknis yang dinaungi dalam perancangan sekolah alam ini.

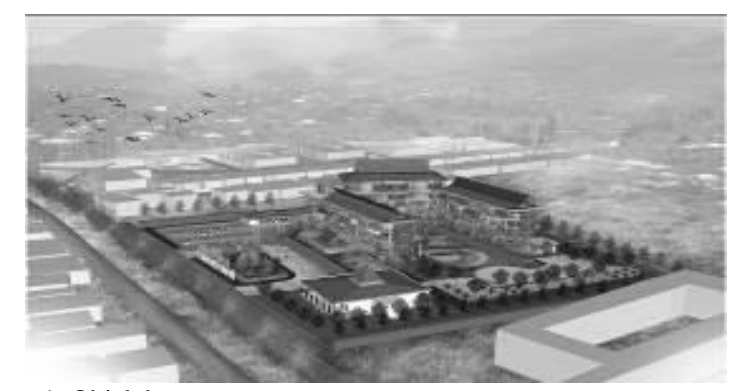

Gambar. 1. Objek bangunan.

(Sumber: Dokumentasi Pribadi)

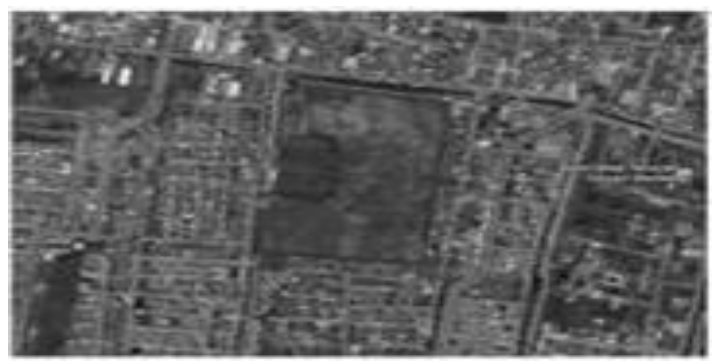

Gambar. 2. Site objek.

(Sumber: www.googleearth.com)
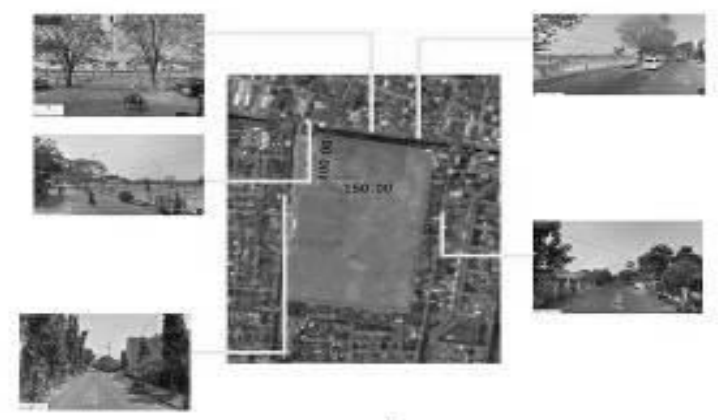

Gambar. 3. Kondisi eksisting site.

(Sumber: www.googleearth.com dan dokumen pribadi)

Sistem teknis dalam bangunan ini bertujuan sebagai inovasi dalam konteks arsitektur secara umum. Di mana kebanyakan sistem utilitas dalam bangunan masih seperti biasanya. Namun 
dalam projek ini, mencoba memodifikasi beberapa sistem utilitas di dalamnya. Dengan menggunakan pendekatan arsitektur berwawasan lingkungan, sehingga diharapkan bagaimana sistem tersebut mampu mereduksi limbah yang dibuang ke lingkungan. Serta adanya sistem daur ulang dan energi alternatif di dalamnya. Maka dari itu adanya beberapa pencapaian dan kesesuaian antara konsep sekolah alam dengan sistem yang ada di dalamnya.

\section{METODA PERANCANGAN}

Berangkat dari beberapa permasalahan dalam desain secara umum dalam pola pengelolaan bangunan. Di mana masih terdapat beberapa kontradiksi yang berhubungan dengan konteks lingkungan. Konsep arsitektur berwawasan lingkungan mengadaptasi dari konsep kolaboratif terhadap alam. Dengan memerhatikan aspek tambahan dalam bangunan untuk merespon lingkungan itu sendiri. Arsitektur ditangani justru dengan merusak alam dengan mengontrol lingkungan memakai alat mekanik seperti AC. Alam mulai rusak, muncul kesadaran memelihara alam beserta sumber energinya serta menjaga kelestariannya. Mulai dipahami bahwa arsitektur yang baik adalah yang bekerja sama dengan alam, bukan dengan memusuhi atau merusaknya [1].

Metode yang digunakan penulis dalam objek rancang ini adalah menggunakan logical argumentation menurut Groat (2002:303) dan aplikasi. Logical argumentation digunakan dalam penarikan parameter untuk menentukan poin-poin yang akan diaplikasikan dalam proses desain. Sedangkan metode aplikasi adalah penerapan langsung ke dalam proses desain, di mana meliputi bagian dari objek bangunan tersebut. Berupa aspek teknis dan sistem dalam arsitekturalnya.

Logical argumentation tersebut didapat dari beberapa nrasumber dalam jurnal penelitian yang sama. Sehingga beberapa parameter dalam merespon permasalah desain tersebut. Parameter tersebut terdiri atas usulan prinsip terhadap pengembangan arsitektur revolusioner (Tsui, Eugene, 1999:38-81)

Prinsip Arsitektur Evolusioner:

a) Pergunakan daur ulang, pembersihan dan sumber kekuatan swasembada

b) Pergunakan material daur ulang dalam konstruksi

c) Kapanpun mungkin, pergunakan bahan bangunan tidak beracun, dan desain untuk menghilangkan pencemaran alam pada bangunan

d) Desain untuk energi, keselamatan air, gempa, perlawanan terhadap binatang kecil pengganggu

e) Desain untuk keselamatan struktural; pergunakan bentuk yang membagi gaya tekan dan regang dengan baik

f) Biarkan bangunan secara internal mengekspresikan pola sikulasi alami pemakainya

g) Hilangkan semua hal yang berlebihan dari desain dan semua prosedur konstruksi yang tak perlu

h) Cari kemajuan di ilmu pengetahuan dan teknologi. Integrasikan dengan 'fitur' fungsional dan estetika dari bangunan dan lokasi i) Lihat bangunan sebagai respon sebuah organisma hidup untuk mengubah ruang dan kebutuhan fungsional

j) Pelihara lingkungan alam dengan memperkecil 'rekam-jejak' bangunan terhadap lahan atau meninggikan bangunan, bila memungkinkan

k) Persatukan semua unsur dari bangunan sebagai sebuah struktural yang ekspresif

1) Kecantikan ekonomi dari alam diekspresikan dalam struktur, bentuk dan material yang ekonomis

m) Melihat ruang sebagai sesuatu yang dinamis, rangkaian multiplanner- hilangkan atap, tembok dan lantai sebagai elemen yang berat; biarkan mereka apa adanya. Ganti jendela dengan langit, matahari dan bintang

n) Semangat dari pengembaraan, risiko, dan tantangan adalah satu ukuran dari kekuatan yang memaksa kita untuk hidup

Dari parameter di atas dapat diambil beberapa parameter untuk ditransformasikan ke dalam proses desain. Yang meliputi:

a) Pergunakan daur ulang, pembersihan dan sumber kekuatan swasembada

b) Desain untuk energi, keselamatan air, gempa, perlawanan terhadap binatang kecil pengganggu.

c) Kemajuan ilmu pengetahuan dan fitur fungsional dan estetika

d) Integrasi unsur bangunan yang ekspresif

e) Melihat ruang menjadi sesuatu yang dinamis, rangkaian multiplanner.

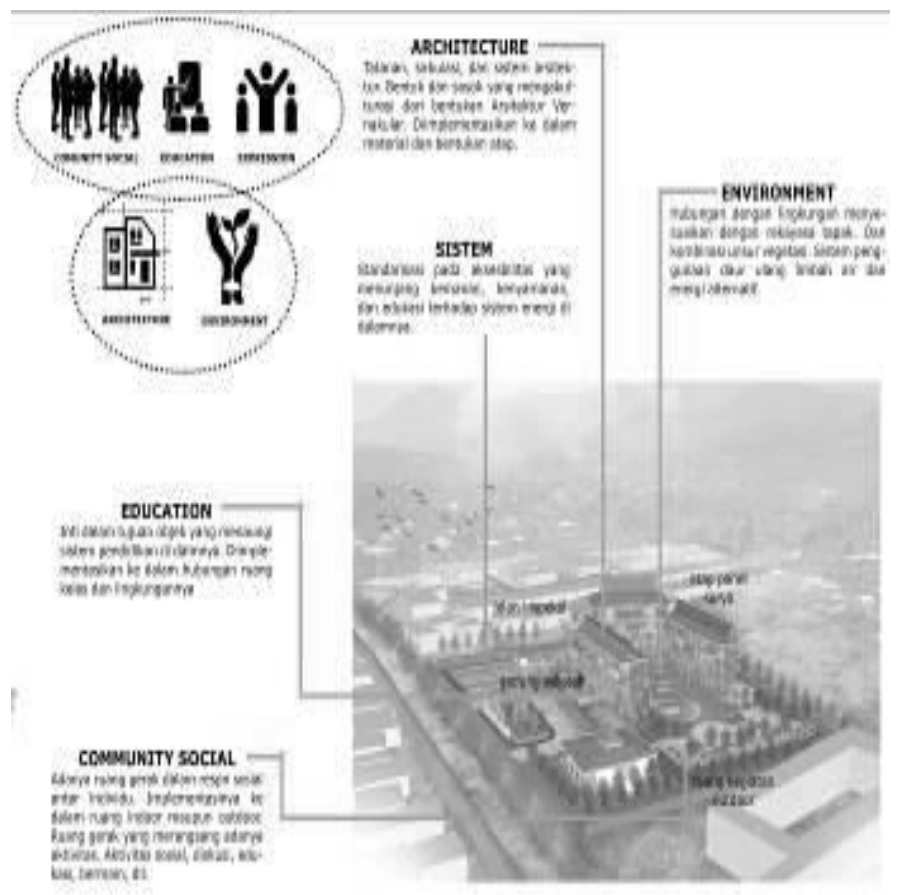

Gambar. 4. Konsep umum pada objek.

(Sumber: dokumen pribadi) 




Gambar. 5. site plan dalam proses desain. (Sumber: dokumen pribadi)

\section{HASIL DAN EKSPLORASI}

Gambaran umum objek keseluruhan berupa gedung sekolah alam. Hal ini merujuk kepada respon objek bangunan terhadap isu yang diangkat. Sedangkan eksplorasi desain dalam penulisan ini adalah bagian dari aspek teknis dalam penunjang bangunan itu sendiri. Hal ini merupaka hasil dari aplikasi parameter rancangan pada uraian di bab sebelumnya. Aplikasi desain ini meliputi aspek material, sistem utilitas, dan aspek ruang luar bangunan.

\section{1) Material}

Merujuk pada poin parameter A dan B, tentang aspek material pada bangunan. Di mana material tersebut berhubungan langsung dengan aspek alam. Material local, yang didapat dari alam, dengan modifikasi dan pengelolaan material tersebut, sehingga mampu meminimalisir limbah dalam aspek daur ulang. Serta penggunaan material tersebut sebagai aplikasi ekspresi pada bangunan. Utamanya aspek interior, yang selain sebagai ekspresi dan estetika, juga sebagai rangsangan psikologis bagi penggunanya. Berupa kesan ruang dari material tersebut.

\section{2) Sistem utilitas}

Aspek teknis di sini meliputi penjabaran dari sistem utilitas yang menunjang bangunan itu sendiri. Meliputi sistem air bersih, air kotor, kelistrikian dan energi alternatif. Hal ini merujuk pada poin parameter A,B,C. Di mana terdapat konsep daur ulang dan fitur terhadap sistem tersebut.

a) Sistem air bersih dan air kotor.
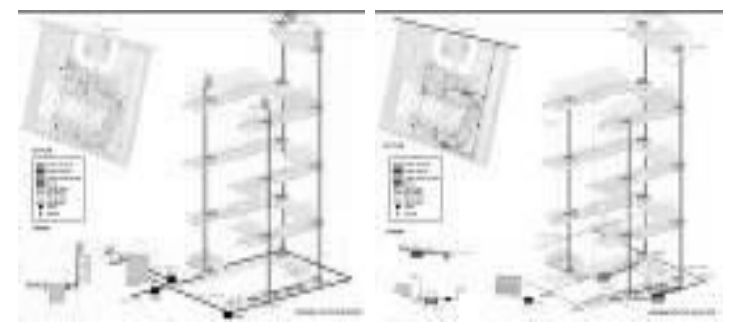

Gambar. 7. sistem air bersih dan air kotor.

(Sumber: dokumen pribadi)

Sistem ini lebih menekankan bagaimana alur dari penggunaan dan penampungan air kotor. Air kotor didaptkan dari limbah pembuangan, kamar mandi, dan sisa air hujan. Menggunakan prinsip reuse. Air reuse ini yang nantinya digunakan dalam aspek pengelolaan bangunan lainnya.

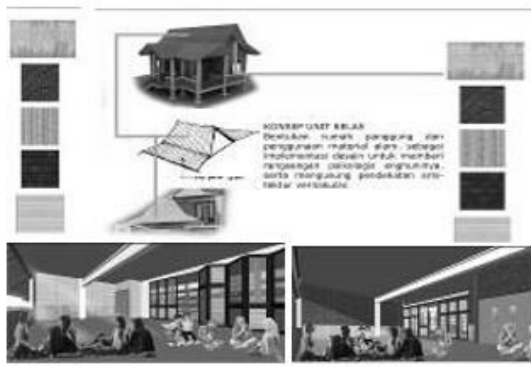

Gambar. 6. Aplikasi material dan interior.

(Sumber: dokumen pribadi)

PRINSIP


Gambar. 8. Prinsip alur system.

(Sumber: dokumen pribadi)

b) Sistem kelistrikan

Gambar. 9. Sistem kelistrikan.

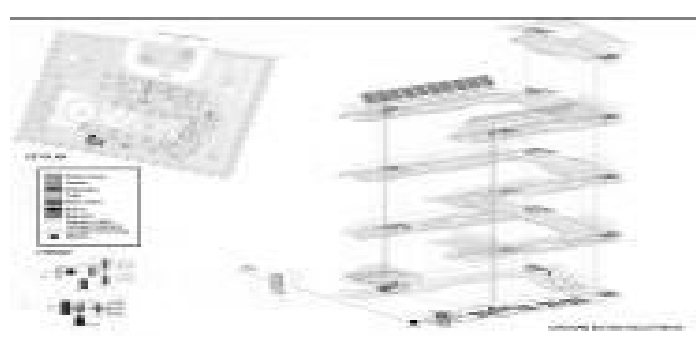

(Sumber: dokumen pribadi)

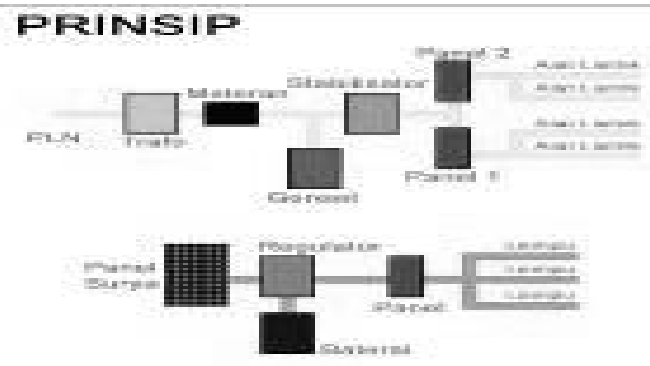

Gambar. 10. Prinsip sistem kelistrikan.

(Sumber: dokumen pribadi) 
Sistem kelistrikan ini secara umum masih disuplai dari PLN. Namun dibantu dengan adanya beberapa jumlah panel surya. Hal ini digunakan sebagai bantuan fitur dalam sistem kelistrikan, juga sebagai edukasi bagi anak-anak tentang energi alternatif.

c) Sistem penghawaan dan pencahayaan

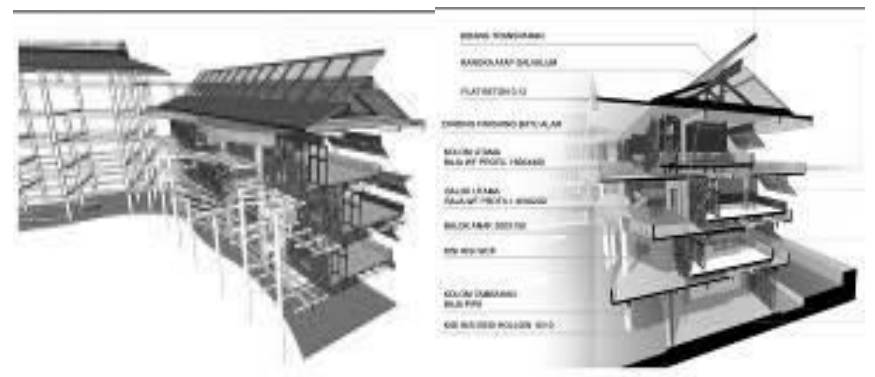

Gambar. 11. Sistem penghawaan dan pencahayaan.

(Sumber: dokumen pribadi)

Sistem struktur dan material dalam bangunan ini berpengaruh pada penghawaan dan pencahayaan. Konsep rongga pada ruang interior dan antar level lantai. Menyesuaikan pada arah datangnya angin, serta porsi jatuhnya sinar matahari / sun direct.

d) Sistem struktur.
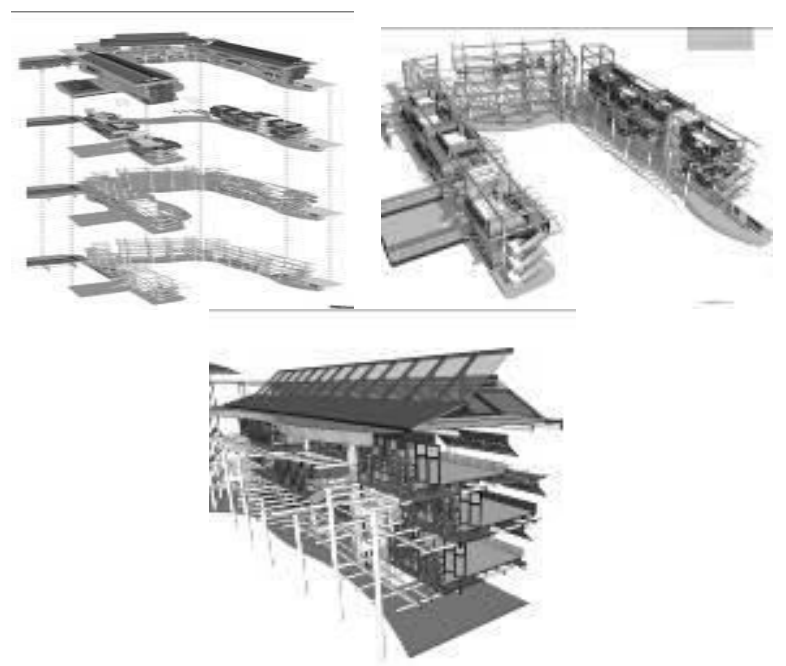

Gambar. 12. Sistem struktur.

(Sumber : dokumen pribadi)

Sistem struktur menyesuaikan dengan pola peletakkan unit ruang kelas. Di mana ruang kelas tersebut disesuaikan dengan arah cross ventilation dalam sistem penghawaan. Serta pola untuk menerima sun direct. Dalam hal ini tentunya perlu modifikasi dan kolaborasi antar sistem struktur. Secara umum menggunakan rigid frame. Dengan tambahan anak struktur untuk mewadahi unit ruang kelas tersebut.

e)

Perancangan luar ruang.
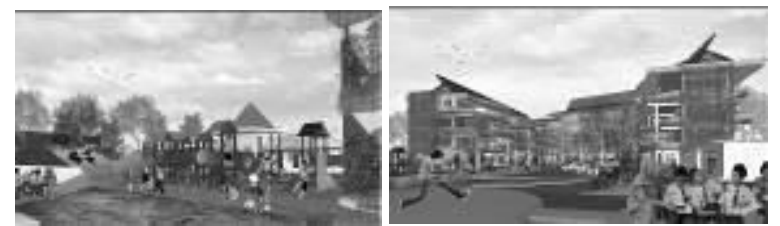

Gambar. 13. Ruang luar.

(Sumber: dokumen pribadi)
Aplikasi arsitektur lingkungan. Dalam aspek perancangan ruang luar. Ruang luar ini bertujuan sebagai wadah aktivitas bagi anak-anak. Baik ditujukan sebagai sarana edukasi, sosialisasi, sekaligus aktivitas yang lainnya. Konsep ruang yang fleksibel dalam aplikasinya.

\section{DOKUMEN GAMBAR}



Gambar. 14. Perspektif dan sikuensi ruang

(Sumber: dokumen pribadi)


Gambar. 15. potongan bangunan

(Sumber: dokumen pribadi)
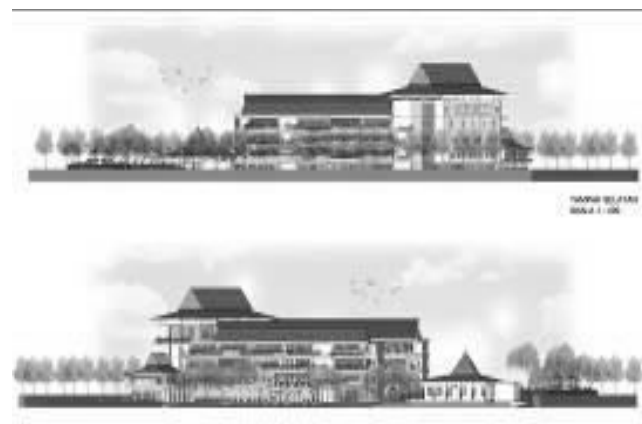

miscos

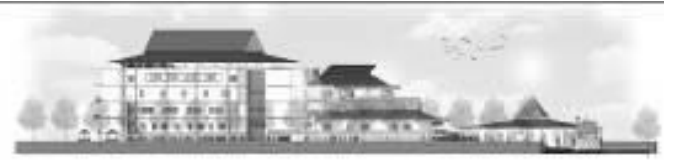

$\tan x$

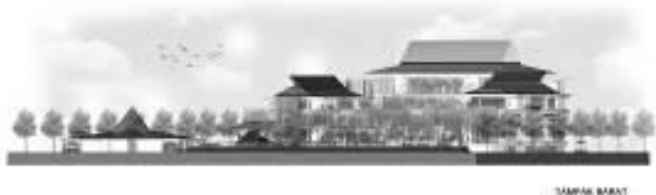

warienent

Gambar. 16. tampak bangunan.

(Sumber: dokumen pribadi) 


\section{KESIMPULAN}

Beberapa tujuan yang berkaitan dengan proses desain sekolah alam lebih kepada aplikasi sistem arsitektur berwawasan lingkungan. Sistem arsitektur dan aplikasi tersebut didapat dari proses penarikan dan aplikasi dari beberapa parameter. Parameter tersebut diambil lebih kurang untuk memberi gagasan dan inovasi baru pada sistem bangunan yang lebih revolusioner, dengan memenadang sistem bangunan selama ini. Utamanya dalam objek geung sekolah.
Penarikan parameter di atas selain sebagai bahan aplikasi pada desain, juga sebagai sarana edukasi tentang pengelolaan energi alternatif pada anak-anak. Selain sebagai kritik arsitektur secara umum. Di mana secara umum objek arsitektur yang berhubungan langsung dengan lingkungan dan alam justru tidak memberi kontribusi dan timbal balik kepada lingkungannya sendiri. $\mathrm{v}$

\section{DAFTAR PUSTAKA}

[1] M. Rachmawati, Pelestarian Alam Dalam Arsitektur: Masalah Dan Usulan Pemecahannya. Surabaya, 2010. 